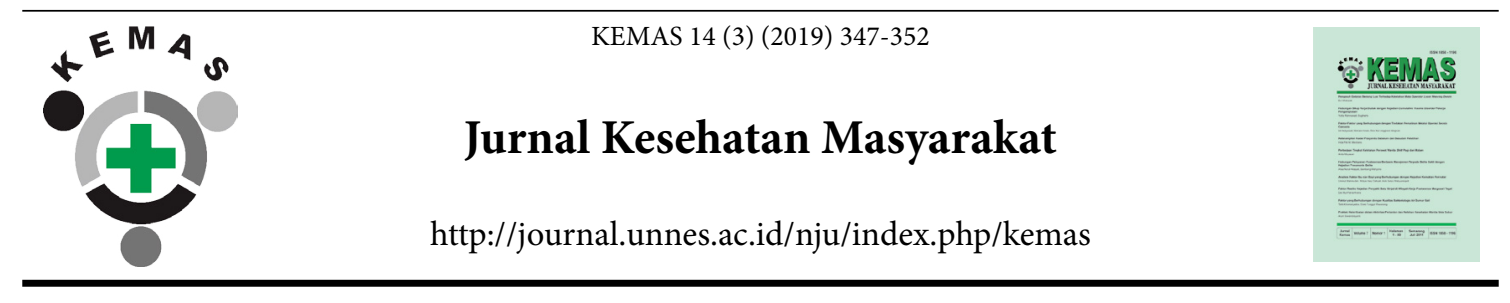

\title{
The Relationship between Previous Tuberculosis Treatment and HIV Status with Multidrug-Resistant Tuberculosis
}

\author{
Dyan Kunthi Nugrahaeni $^{1}$, Salma Zaqiya ${ }^{1}$ \\ ${ }^{1}$ Public Health Study Program, School of Health Sciences Jenderal Achmad Yani Cimahi, Indonesia
}

\begin{abstract}
Multidrug-resistant tuberculosis (MDR-TB) is becoming major public health issues in the world. Among the causes are history of previous TB treatment and increased co-infection of TB-HIV (Human Immunodeficiency Virus). This study aimed to identify the relationship between history of previous TB treatment and HIV status with MDR-TB. This is a case control study. The sample case was patients with MDR-TB, while sample control was patient who have drug-sensitive TB. Secondary data was obtained from patient medical records and laboratory results at Rotinsulu Pulmonary Hospital Bandung. Data were analyzed using chi-square. Multiple logistic regression was used to identify the dominant factor that influence the occurrence of MDR-TB. This study showed that the history of previous TB treatment was statistically significant with MDR-TB ( $\mathrm{p}$ value $=$ $0.001 ; \mathrm{OR}=18.889 ; 95 \% \mathrm{CI}=4.093-87.172)$ and it is the dominant factor that influence MDR-TB ( $\mathrm{p}$ value $=0.0001 ; \mathrm{OR}=56.84 ; 95 \% \mathrm{CI}=6.9-468.87$ ). HIV infection at control group (who contracted drug-sensitive TB) was $26.1 \%$ ( $\mathrm{p}$ value $=0.022$ ). This finding suggested that HIV testing should be performed to each TB and MDR-TB patients and increased collaboration TB-HIV program between the other health care facilities should ensue. Drug sensitivity testing should be conducted at the start of TB treatment for patients with previous TB treatment and TB-HIV co-infection.
\end{abstract}

\section{Introduction}

Tuberculosis (TB) is a contagious infectious disease caused by the bacteria Mycobacterium tuberculosis. In 2015, World Health Organization (WHO) estimated 10.4 million new incidents of TB cases worldwide. People living with HIV (Human Immunodeficiency Virus) accounted for 1.2 million $(11 \%)$ of all new TB cases. An estimated 1.4 million deaths are related to TB, and additional 0.4 million deaths from TB disease among people living with HIV (Dean et al., 2017). Indonesia has the second highest TB prevalence in the world after India. The estimated number of TB patients in Indonesia is $10 \%$ of all $\mathrm{TB}$ patients globally. Unfortunately, many cases of uncured $\mathrm{TB}$ resulted in new problems of multidrug-resistant TB (MDRTB). MDR-TB is Mycobacterium tuberculosis resistant to at least two first-line antituberculosis drugs, especially rifampicin and isoniazid (Louw et al., 2009).

The incidence of MDR-TB in 2015 amounted to $3.9 \%$ ofnewcases, with an estimated 580.000 cases and $21 \%$ from previously treated TB cases (Dean et al., 2017). Drug resistance tuberculosis was caused by inadequate treatment. The most important risk factor for MDR-TB is history of previous treatment. Other risk factors include hospitalization, 
incarceration and HIV infection (Dean et al., 2017). Previous tuberculosis treatment is associated with 10 times or greater risk of MDR-TB compared with patients who have not been previously treated with tuberculosis drugs (Burhan, 2010). Main causes of MDRTB are poor implementation of DOTS program (Directly Observed Treatment Short-course) in hospitals and health care facilities, inadequate supply of quality drugs, inadequate patient compliance and other factors, such as HIV infection (Hanf et al., 2012).

Inadequate treatment of tuberculosis induces gene mutation in the bacteria and cause resistance to anti-tuberculosis drugs such as isoniazid and rifampicin. In the Mycobacteria, the influx of toxic compounds is significantly restricted by the complex cell wall, and the lipid bilayer presents a significant barrier to the influx of antibiotics. Decreased intracellular concentrations of more than one antibiotic may lead to increased resistance to multiple anti-TB drugs (Louw et al., 2009).

MDR-TB can either be primary or secondary resistance. Primary resistance occurs in patients who have never received prior treatment. Primary resistance is usually found in patients with HIV infection. Secondary resistance is obtained during therapy in people who is previously sensitive to drug (Sharma \& Mohan, 2004). Increased TB-HIV co-infection affects the progression of the disease, prolong the period of infection, and increase risk of MDR-TB (Soepandi, 2012) due to weaker immune system in people with HIV (Sharma \& Mohan, 2004).

Rotinsulu Pulmonary Hospital Bandung in 2005 found that $28.2 \%$ were resistant to rifampicin-isoniazid; $17.8 \%$ resistant to rifampicin-isoniazid-ethambutol; and $13.8 \%$ resistant to rifampicin-isoniazid-ethambutolpyrazinamide-streptomycin. A study in 2010 found $80.8 \%$ were categorized as MDR-TB and the remaining $19.2 \%$ as Extensively Drugresistant TB (XDR-TB) (Nugrahaeni \& Malik, 2013). This study aimed to understand the relationship between history of previous $\mathrm{TB}$ treatment and HIV status with MDR-TB at Rotinsulu Pulmonary Hospital Bandung.

Method

This is a case control study that compares cases with controls, and looks back retrospectively to compare the exposure in each group to determine the relationship between the risk factor and disease. Data was collected from medical records of patient with multidrugresistant tuberculosis and drugs-sensitive tuberculosis from January to December 2014 in Rotinsulu Pulmonary Hospital Bandung.

Sample cases in this study were defined as person with MDR-TB (person infected with an isolate resistant to at least isoniazid and rifampicin) based on clinical diagnosis, bacterial culture and anti-TB susceptibility testing. We identified 23 person. Sample controls are defined as people with drugsensitive tuberculosis based on acid fast bacilli and chest X-ray test. We identified 23 person. Sample control was age and gender-matched to the sample case. Patients with pregnancy, diabetes mellitus, and cancer were excluded from this study.

The variables used in this study are the following: patient characteristic (level of education and employment jobs), type of resistant anti-TB drug, type of tuberculosis, history of previous TB treatment, and HIV status. Univariate analysis was conducted to obtain frequency distribution variable, while bivariate analysis was conducted using chisquare test. Multivariate analysis using multiple logistic regression was used to determine the final multivariate model and to identify the dominant factor that influences the occurrence of MDR-TB.

This study used medical record register of patient with multidrug-resistant tuberculosis and drugs sensitive tuberculosis. This study have been carried out according to ethical, legal, social implications and other applicable regulation. This study passed Ethical clearance and has been approved by Health Research Ethics Committee, Faculty of Medicine, Universitas Pajadjaran Bandung (approval No. 418/UN6.C1.3.2/KEPK/PN/2015, 25 June 2015).

\section{Result and Discussion}

Multidrug-resistant tuberculosis (MDRTB) patients determined on the basis of clinical diagnosis, bacterial culture from sputum and anti-TB drug susceptibility test was defined as sample cases. Whereas sample control are 


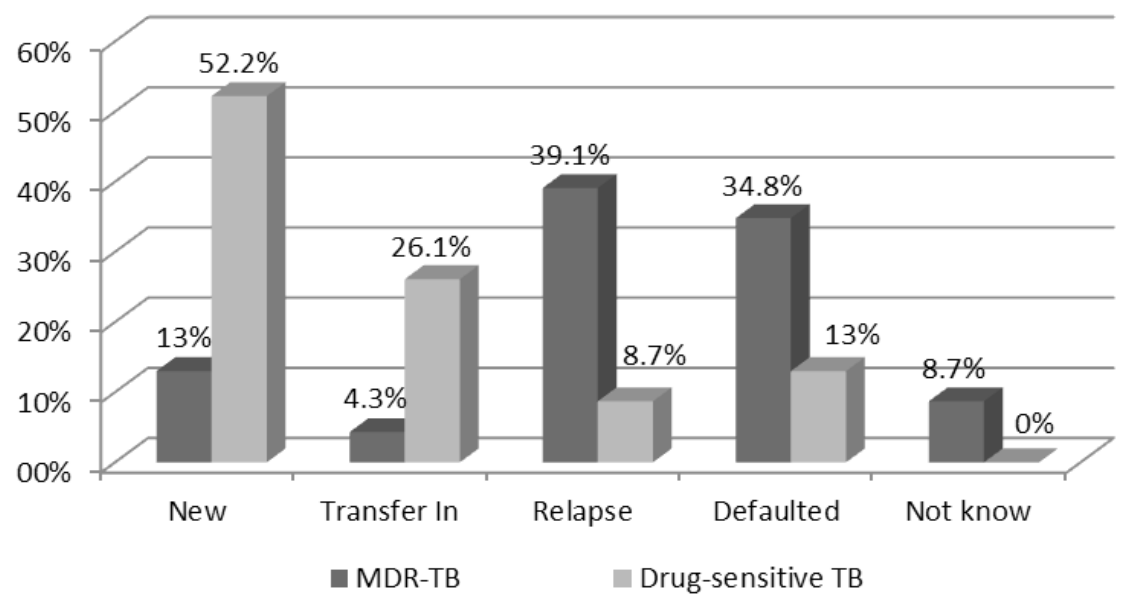

Figure 1. Type of MDR-TB patient

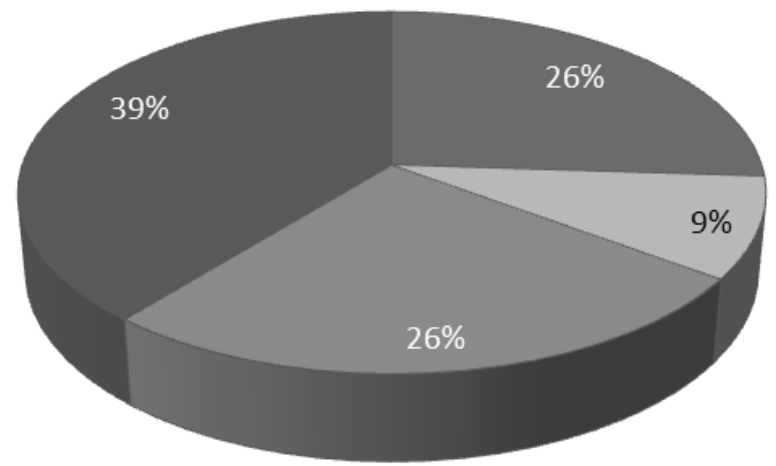

Rifampisin dan isoniazid

$\square$ Rifampisin, isoniazid dan ethambutol $\square$ Rifampisin, isoniazid dan streptomysin

口ifampisin, isoniazid, ethambutol dan streptomysin

Figure 2. The Distribution of the Resistance Type of MDR-TB Patient

patients with drug-sensitive TB based on acid fast bacilli and chest X-ray test.

This study founded that of all MDR-TB patients who have received previous treatment with anti-TB drug, $39.1 \%$ was considered treatment relapse (bacteriologically positive tuberculosis following previously cured TB), and $34.8 \%$ was considered treatment default (interruption of treatment for $\geq 2$ consecutive months) (figure 1).

MDR-TB patients resistant to four (4) potentially anti-TB drugs (rifampicin, isoniazid, Ethambutol, and Streptomysin) were $39 \%$ (figure 2). The occurrence of resistance to the combination of four (4) anti-TB drugs in this study has increased compared to previous studies at Rotinsulu Pulmonary Hospital 2010 which amounted to $15.4 \%$ (Nugrahaeni \& Malik, 2013).

Characteristic distribution of MDR-TB patients were as following: $39.1 \%$ is a housewife and $65.2 \%$ have elementary education level. Up to $87 \%$ of patients with prior TB treatment were diagnosed with MDR-TB (Table 1). History of previous $\mathrm{TB}$ treatment was statistically significant with the occurrence of MDR-TB ( $\mathrm{p}$ value $=0.001)$, Odds Ratio $(\mathrm{OR}=18.889 ; 95 \%$ $\mathrm{CI}=4.093-87.172)$. This study was consistent 
Table 1. The Relationship History of Previous TB Treatment and HIV Status with the Occurrence of MDR-TB

\begin{tabular}{|c|c|c|c|c|c|c|c|c|c|}
\hline \multirow{2}{*}{ Variable } & \multirow{2}{*}{ Category } & \multicolumn{2}{|c|}{ Case } & \multicolumn{2}{|c|}{ Control } & \multicolumn{2}{|c|}{ Total } & \multirow{2}{*}{$\mathrm{P}$ value } & \multirow{2}{*}{$\begin{array}{l}\text { OR } \\
(95 \% \mathrm{CI})\end{array}$} \\
\hline & & $\mathrm{n}$ & $\%$ & $\mathrm{n}$ & $\%$ & $\mathrm{n}$ & $\%$ & & \\
\hline \multirow{2}{*}{ Level of Education } & $\begin{array}{l}\text { Elementary } \\
\text { education }\end{array}$ & 15 & 65.2 & 14 & 60.8 & 29 & 63.0 & \multirow{2}{*}{0.76} & \multirow{2}{*}{$\begin{array}{l}1.2 \\
(0.36-3.99)\end{array}$} \\
\hline & $\begin{array}{l}\text { Higher } \\
\text { education }\end{array}$ & 8 & 34.8 & 9 & 39.1 & 17 & 37.0 & & \\
\hline \multirow{4}{*}{ Employment Jobs } & $\begin{array}{l}\text { Government } \\
\text { employees }\end{array}$ & 2 & 8.70 & 1 & 4.3 & 3 & 6.50 & \multirow{4}{*}{0.625} & \\
\hline & Private sector & 11 & 47.8 & 14 & 60.9 & 25 & 54.3 & & \\
\hline & Housewife & 9 & 39.1 & 8 & 34.8 & 17 & 37.0 & & \\
\hline & Student & 1 & 4.3 & 0 & 0 & 1 & 2.2 & & \\
\hline \multirow{2}{*}{$\begin{array}{l}\text { History of } \\
\text { Previous TB } \\
\text { Treatment }\end{array}$} & $\begin{array}{l}\text { Previously } \\
\text { treated case } \\
(1-5 \text { times })\end{array}$ & 20 & 87 & 6 & 26.1 & 26 & 56.5 & \multirow[t]{2}{*}{0.001} & \multirow[t]{2}{*}{$\begin{array}{l}18.9 \\
(4.093-87.172)\end{array}$} \\
\hline & New case & 3 & 13 & 17 & 73.9 & 20 & 43.5 & & \\
\hline \multirow{2}{*}{ HIV Status } & Positive & 0 & 0 & 6 & 26.1 & 6 & 13.0 & \multirow{2}{*}{0.022} & \\
\hline & Negative & 23 & 100 & 17 & 73.9 & 40 & 87.0 & & \\
\hline Total & & 23 & 100 & 23 & 100 & 46 & 100 & & \\
\hline
\end{tabular}

Sourch: Medical Record Rotinsulu Pulmonary Hospital Bandung, 2014

with a study in Belarus, Russia (2010-2011) in which the majority $(75.6 \%)$ of MDR-TB patients have a history of previous TB treatment. History of previous treatment for $\mathrm{TB}$ was the strongest independent risk factor for $\mathrm{MDR}-\mathrm{TB}(\mathrm{OR}=6.5$; 95\% CI= 5.2 - 8.2) (Skrahina, 2012).

HIV infection in sample control (respondents with drug-sensitive TB) was $26.1 \%$. The present study found an association between HIV infection and MDR-TB (p value= 0.022). In Europe, Faustini, Hall, and Perucci (2005) found that HIV status was significantly associated with the occurrence of MDR-TB $(\mathrm{OR}=3.52 ; 95 \% \mathrm{CI}=2.48-5.01)$. A study in Belarus, Russia, found that HIV co-infection with $\mathrm{TB}$ is a risk factor for MDR-TB ( $\mathrm{p}$ value= 0.0001; $\mathrm{OR}=2.6,95 \% \mathrm{CI}=1.7-4.1$ ).

In the final multivariate model, independent variables that influences the occurrence of MDR-TB are occupation, level of education and history of past TB treatment. History of previous TB treatment is the dominant factor that influences the occurrence of MDR-TB ( $\mathrm{p}$ value $=0.0001 ; \mathrm{OR}=56.84 ; 95 \%$ $\mathrm{CI}=6.9-468.87)($ Table 2).

Tuberculosis control and eradication strategies are constraint by MDR-TB as it increase complexities in diagnosis and treatment failure of tuberculosis, leading to higher mortality rate in MDR-TB (Suchindran et al., 2009). Multidrug-resistant tuberculosis is tuberculosis infection caused by Mycobacterium tuberculosis that are resistant to at least two of the first-line anti-TB drugs, such as isoniazid and rifampicin. In this study, we founded $26.1 \%$ of patients was resistant to isoniazid and rifampisin.

MDR-TB was caused by inadequate $\mathrm{TB}$ treatment such as, monotherapy drugs, noncompliance with treatment, extreme poverty, intolerance to medication and shortage of medication. These conditions allow development of resistance to anti-TB drugs (acquired MDR-TB or direct transmission of

Table 2. Multivariate Analysis of the Occurrence of MDR-TB

\begin{tabular}{llll}
\hline Variable & B & P Value & OR (95\% CI) \\
\hline Occupation & -1.167 & 0.099 & $0.31(0.078-1.25)$ \\
\hline Level of Education & 1.449 & 0.124 & $4.2(0.67-27.04)$ \\
\hline History of previous TB treatment & 4.04 & 0.0001 & $56.84(6.9-468.87)$ \\
\hline
\end{tabular}

Sourch: Medical Record Rotinsulu Pulmonary Hospital Bandung, 2014 
of patients suffering from MDR as a primary MDR-TB (Suchindran et al., 2009). Based on basic health research 2010, as many as $38.11 \%$ and $21.95 \%$ of pulmonary tuberculosis patients in private health care facilities and public health facilities, respectively, do not adhere to treatment. $(\mathrm{OR}=2.19 ; 95 \% \mathrm{CI}: 1.61-2.97)$ (Fadila \& Riono, 2014).

Past TB treatment can cause multidrugresistant tuberculosis. Most MDR-TB patients have treatment relapse and default. Relapse and defaulted in tuberculosis treatment could cause inadequate treatment, allowing the Mycobacterium tuberculosis to acquire resistance against anti-TB drugs (Soepandi, 2010). Tuberculosis patient who receive irreguler treatment of tuberculosis drug had a 2.3 times greater risk of developing MDR-TB than those taking reguler treatment $(\mathrm{P}$ Value $=$ 0.01, OR=2.3, 95\% CI = 1.38-10.28) (Sarwani et al., 2012)

In this study, MDR-TB patient with no history of previous TB treatment (new tuberculosis case) was $13.0 \%$. It is unknown whether or not the patients ever had a history of contact with MDR TB, referred to as primary MDR-TB. People with new MDR-TB case indicates transmission of resistant strains of M. tuberculosis in the community (Skrahina, 2012). The high number of people with MDR$\mathrm{TB}$ among new $\mathrm{TB}$ cases indicates transmission of resistant strains of $\mathrm{M}$. tuberculosis in the community (Skrahina, 2012). In this study, the extent of transmission of resistant strains could not be assessed and further studies based on genotyping should be conducted. The prevalence of MDR-TB was estimated to be up to 10 times higher in unsuccessful treatment (Faustini, 2006). We found that patients with previous tuberculosis treatment are at 18.9 times higher risk of MDR-TB. The dominant variable attributed to MDR-TB are past $\mathrm{TB}$ treatment and it can be predicted as the causes of $\mathrm{MDR}-\mathrm{TB}(\mathrm{OR}=56.84 ; 95 \% \mathrm{CI}=6.9$ - 468.87).

The association between HIV infection and TB infection or MDR-TB can be caused by multiple factors. The first factor is association with time window, where in HIV infected patients, the progression of the disease are rapid and can lead to co-infection of HIVTB through community or institutional transmission (Suchindran et al., 2009). The association between HIV infection and MDRTB may be confounded by risk factors, such as injection drug use, socioeconomic status, and hospitalization.

The incidence and mortality rates for new AIDS-defining opportunistic infections have been shown to be higher if individuals with HIV are co-infected with TB. HIV patients should avoid risk factors of contracting TB or MDR-TB disease. Therefore, there is a need for collaboration between HIV and TB prevention programs, through screening tests for $\mathrm{TB}$ and HIV patients. Infection control measures need to become a key element of global TB control.

\section{Conclusion}

Previous anti-TB treatment must be identified in each tuberculosis patients at all level of health facilities because they are at increased risk of drug resistance, including MDR-TB. Although some characteristics of TB treatment such as defaulting from treatment and relapsing are well known predictors of multidrug-resistant tuberculosis, other aspects of treatment such as the drugs used and the length of treatment need to be studied as they may contribute to improving control program.

Determining and recording the patient's HIV status is critical for treatment decisions as well as for monitoring trends and assessing program performance. Collaboration of $\mathrm{TB}$ and HIV/AIDS program between hospitals and that health care facilities that implement DOTS is required to reduce the burden of HIV in people diagnosed with TB and people living with HIV. Drugs sensitivity testing should be performed at the start of TB treatment in patients previously treated with anti-TB drugs and HIV-positive TB patients to avoid mortality due to unrecognized drug-resistant TB. The use of rapid DST (Drug Sensitivity Testing) in sputum smear-positive persons living with HIV is strongly encouraged.

\section{Acknowledgments}

We are grateful of all those who contributed to our study, of Institute for Research and Community Services School of Health Sciences Jenderal Achmad Yani Cimahi, of patient with multidrug-resistant tuberculosis and drugs sensitive tuberculosis and of staff at Rotinsulu Pulmonary Hospital Bandung. We 
thank lecturer at Public Health Study Program, School of Health Sciences Jenderal Achmad Yani.

\section{Reference}

Burhan, E., 2010. Peran International Standards for Tuberculosis Care dalam Pencegahan MDR. Jurnal Tuberkulosis Indonesia, 7, pp. 12-15.

Dean, A., Cox, H., \& Zignol, M., 2017. Epidemiology of Drug-Resistant Tuberculosis. Advances in Experimental Medicine and Biology, 1019, pp. 209-220.

Fadila, R.N., \& Riono, P., 2014. Pengaruh Rejimen terhadap Ketidakpatuhan Berobat Tuberkulosis. Jurnal Kesehatan Masyarakat Nasional, 9, pp. 107-112.

Faustini., Hall., \& Perruci., 2006. Risk Factors for Multidrug Resistant Tuberculosis in Europe: A Systematic Review. pp. 158-163.

Hanf, M., Adenis, A., Coippie, P., Carme, B., Nacher, M., 2012. The Impact of Corruption on Multidrug-Resistant Tuberculosis: a Quantitative Assessment. European Respiratory Journal, 40(3), pp. 792-793.

Louw, G.E., Warren, R.M., Pittius, V.G., McEvoy, C. R. E., Helden, V.P.D., 2009. Minireview a Balancing Act : Efflux/Influx In Mycobacterial Drug Resistance. Antimicrobial Agent and
Chemotherapy, 53(8), pp. 3181-3189.

Nugrahaeni, D.K., \& Malik, U.S., 2013. Analisis Penyebab Resistensi Obat Anti Tuberkulosis. Jurnal Kesehatan Masyarakat, 8(2), pp. 113120.

Sarwani, D., Nurlaela, S., \& Zuhrotul, I., 2012. Faktor Risiko Multidrug Resistant Tuberculosis (Mdr-Tb). Jurnal Kesehatan Masyarakat, 8(1), pp. 60-66.

Sharma, S., \& Mohan, A., 2004. Multidrug-resistant Tuberculosis. Indian J Med Res, 120(4), pp. 354-376.

Skrahina, A., 2012. Multidrug Resistant Tuberculosis in Belarus: The Size of The Problem and Associated Risk Factors. Bulletin of The World Helath Organization, 91(1), pp. 36-45.

Soepandi., 2010. Diagnosis dan Penatalaksaaan TB-MDR. Cermin Dunia Kedokteran, pp. 497-500.

Soepandi, P., 2012. Diagnosis dan Faktor yang mempengaruhi terjadinya TB-MDR. Jurnal Tuberkulosis Indonesia, 8.

Suchindran, S., Brouwer, E.S., \& Van Rie, A., 2009. Is HIV Infection a Risk Factor for Multi-Drug Resistant Tuberculosis? A Systematic Review. PLoS ONE, 4(5), pp. e5561. 